\title{
COVID-19 and the Scope of the UN Security Council's Mandate to Address Non-Traditional Threats to International Peace and Security
}

\author{
Erin Pobjie*
}

Senior Research Fellow, Max Planck Institute for Comparative Public Law and International Law, Heidelberg, Germany

pobjie@mpil.de

Keywords

I. Introduction

II. COVID-19 as an Endangerment to International Peace and Security

1. 'Threat/Endangerment to International Peace and Security' vs 'Threat to the Peace' 120

2. Transnational Health Crises as Endangerments to International Peace and Security 123

3. The Scope of the Security Council's Mandate under Article 24(1) 125

4. General Powers Stemming from Article 24(1) 126

5. Conclusion

III. Interpretation of 'International Peace and Security' in Article 24(1)

1. UN Charter Interpretation

2. Security Council Resolutions as 'Subsequent Practice'

3. Evolution of the Interpretation of 'International Peace and Security' 133

4. Security Council Practice Addressing Transnational Health Crises 136

5. Conclusion 139

$\begin{array}{ll}\text { IV. Implications } & 140\end{array}$

1. Risk of Securitisation of Global Health 141

2. Potential for Global Coordination of Response 142

3. Challenges of Coordination between Specialised UN Agencies 143

4. Implications for Collective Security Framework 144

5. Conclusion 145

V. Conclusion: Reconceptualising Collective Security and the Role of the Security
Council

\begin{abstract}
In Resolution 2532 (2020), the UN Security Council characterised the COVID-19 pandemic as an endangerment to international peace and security and, for the first time, demanded a general ceasefire and humanitarian pause
\end{abstract}

\footnotetext{
* The author would like to thank Anne Peters and Chrisitan Marxsen for their thoughtful comments on an earlier version of this article.
} 
in armed conflicts across the globe. This article analyses the resolution and its broader implications. In particular, it examines the significance of the Council's characterisation of the COVID-19 pandemic, the binding powers of the Security Council for addressing threats to international peace and security which are not 'threats to the peace', and the implications for the Council's mandate and the collective security framework. This article argues that the concept of 'international peace and security' under Article 24(1) of the United Nations (UN) Charter - rather than Article 39 'threats to the peace' - is fundamental to the delimitation of the Security Council's mandate and powers for addressing non-traditional threats to international peace and security such as pandemics and the climate crisis.

\section{Keywords}

COVID-19 - Resolution 2532 - Security Council - threat to international peace and security - threat to the peace

\section{Introduction}

On 1 July 2020, for the first time in its history, the United Nations Security Council adopted a resolution demanding a general ceasefire and humanitarian pause in armed conflicts across the globe. At this point, the general context of UN Security Council Resolution 25321 - the global COVID-19 pandemic - is a matter of shared experience and is well known. Readers will recall that on 11 March 2020, the World Health Organisation (WHO) declared COVID-19 to be a global pandemic. The UN Secretary General António Guterres took the initiative twelve days later to call for a global ceasefire to focus efforts on fighting the pandemic and open humanitarian corridors to deliver aid to those most vulnerable. ${ }^{2}$ The UN General Assembly followed by passing Resolution 74/270 on 2 April calling for intensified international cooperation to contain, mitigate and defeat the pandemic'. ${ }^{3}$ Amidst exponentially rising case numbers, fatalities and increasingly apparent global consequences of the pandemic, the Security Council remained frustratingly silent, embroiled in political disagreements between its permanent members, most notably China and the United States. Finally,

1 UN Doc. S/RES/2532 (2020).

2 'The fury of the virus illustrates the folly of war', <www.un.org>, 23 March 2020.

3 'Global solidarity to fight the coronavirus disease 2019 (COVID-19)', UN Doc. A/RES/ $74 / 270$. 
on 1 July 2020, this impasse was broken and the Council unanimously adopted Resolution 2532. Though its practical and symbolic impact was vastly diminished by the delay in the Council's response, the resolution is still highly significant. In Resolution 2532, the Security Council '[c]onsider[s] that the unprecedented extent of the COVID-19 pandemic is likely to endanger the maintenance of international peace and security', ${ }^{4}$ and took measures including to 'demand[...] a general and immediate cessation of hostilities in all situations on its agenda's and to 'call[...] upon all parties to armed conflicts to engage immediately in a durable humanitarian pause for at least 90 consecutive days, in order to enable the safe, unhindered and sustained delivery of humanitarian assistance, provisions of related services by impartial humanitarian actors, in accordance with the humanitarian principles of humanity, neutrality, impartiality and independence, and medical evacuations, in accordance with international law, including international humanitarian law and refugee law as applicable'. ${ }^{6}$

The Security Council's characterisation of the COVID-19 pandemic as an endangerment of international peace and security and not a 'threat to the peace' under Article 39 of the Charter gives rise to important legal implications. First of all, as will be shown, this characterisation relates to Article 24(1) of the UN Charter and constitutes subsequent practice in its interpretation. As this paper argues, Article 24(1) sets out the scope of the Security Council's mandate and gives rise to general express and implied powers, which the Council may exercise to make binding decisions outside Chapter VII. Resolution 2532 thus contributes to an evolutive interpretation of the scope of the Council's mandate to maintain international peace and security. This expanded notion of 'international peace and security' has implications not only for the role of the Security Council in addressing non-conventional global threats but also for the collective security framework of the United Nations. It therefore represents a risk but also an opportunity for reimagining the protected object of this framework, beyond military security towards a broader understanding of human security. This article argues that the concept of 'international peace and security' under Article 24(1) of the UN Charter - rather than Article 39 'threats to the peace' - is fundamental to the delimita-

4 UN Doc. S/RES/2532 (2020), Preambular para. 11, emphasis added.

5 UN Doc. S/RES/2532 (2020), para. 1.

6 UN Doc. S/RES/2532 (2020), para. 2. Other measures include requests that the SecretaryGeneral provide updates and the coordination of the response within the UN system including UN Country Teams (paras. 4 and 5), and to instruct peace-keeping operations to support host country authorities and the protection of safety, security and health of UN personnel in UN peace operations (para. 6) in addition to a general call for action to minimise disproportionate negative impact of the pandemic on especially vulnerable groups including women and girls (para. 7). 
tion of the Security Council's role and powers for addressing non-traditional threats to international peace and security such as pandemics and the climate crisis. To wit: what is the meaning of 'international peace and security'? What action may the Council take with respect to acts which endanger international peace and security but which it does not characterise as a 'threat to the peace' under Chapter VII, and are those measures binding on UN Member States? And what are the implications of these answers for the role of the UN Security Council, as well as more broadly for the collective security system enshrined in the UN Charter? This article addresses these questions through the lens of Resolution 2532 and the role of the Security Council in addressing the COVID-19 pandemic.

\section{COVID-19 as an Endangerment to International Peace and Security}

The most legally interesting feature of Resolution 2532 is its characterisation of the COVID-19 pandemic as 'likely to endanger the maintenance of international peace and security'7 and not as a 'threat to the peace'. This is a legally significant distinction for two reasons: firstly, it means that, together with the precedents of the Council addressing transnational health crises, Resolution 2532 counts as subsequent practice affecting the interpretation of the concept of 'international peace and security' in the UN Charter. This in turn affects the scope of the Security Council's mandate in Article 24(1), which confers upon it primary responsibility to maintain international peace and security and is also the basis for its general express and implied powers.

\section{1. 'Threat/Endangerment to International Peace and Security' vs 'Threat to the Peace'}

Due to its pivotal role in empowering the Security Council to take enforcement action under Chapter VII, much scholarly attention has been devoted to the meaning of 'threat to the peace', the extent of the Council's discretion in interpreting this term and its justiciability. ${ }^{8}$ However, the litera-

7 UN Doc. S/RES/2532 (2020), Preambular para. 11.

8 See Nico Krisch, 'Article 39', in: Bruno Simma, Daniel-Erasmus Khan, Georg Nolte, Andreas Paulus and Nikolai Wessendorf (eds), The Charter of the United Nations: A Commentary (3rd edn, Oxford: Oxford University Press 2012), 1272 - 1296 for further extensive references. 
ture often conflates 'threats to international peace and security' with 'threats to the peace'. ${ }^{9}$ This conflation of the two terms in scholarship reflects inconsistent practice by the Council itself in the usage of these terms: in some resolutions which are cited as part of a trend towards an expansion of the concept of 'threats to the peace', such as Resolution 794 (1992) on Somalia, Resolution 955 (1994) on Rwanda, Resolution 1529 (2004) on Haiti, and Resolution 1735 (2006) on Al-Qaida and the Taliban, the Security Council characterises the situation as a 'threat to international peace and security' rather than a 'threat to the peace' but still explicitly calls for Chapter VII measures to be adopted. This inconsistent usage of terms may reflect the way resolutions are drafted through negotiation and political compromise, usually not by lawyers, ${ }^{10}$ and may even be a form of constructive ambiguity leaving open the interpretation without explicitly stating that a resolution is adopted under Chapter VII when there is a lack of consensus among Council members.

Based on the escalation in measures available in response, it is a reasonable interpretation that the threshold of 'threat to the peace' is higher, requiring a higher degree of risk (in terms of likelihood of its materialisation) and a higher magnitude of risk (level of damage), than for a finding of an endangerment to the maintenance of international peace and security. ${ }^{11}$ Alternatively, it could be objected that the latter term requires that two conditions must be cumulatively satisfied, namely an endangerment to peace as well as to security, resulting in a higher threshold than for a 'threat to the peace'. But arguably the word 'and' in the term 'international peace and security' in the

9 For example, the Max Planck Encyclopedia of Public International Law entry of Erika De Wet, 'Peace, Threat To' in: Rüdiger Wolfrum (ed.) MPEPIL (Oxford: Oxford University Press 2015), 3, para. 8, lists examples of 'threats to the peace' in the Security Council's practice which were in fact characterised not as 'threats to the peace' but 'threats to international peace and security', such as illicit trafficking in small arms and light weapons (UN Doc. S/PRST/2006/38 (West Africa), in which 'The Security Council considers that illicit trafficking in small arms and light weapons still poses a threat to peace and security in the region' (para. 6); acts of international terrorism (in which the Council stated, 'terrorism in all its forms and manifestations constitutes one of the most serious threats to international peace and security': UN Doc. S/ PRST/2006/30, under agenda item 'Threats to international peace and security caused by terrorist acts'), proliferation of weapons of mass destruction (UN Doc. S/RES/1467 (2003) in which the Council held 'a nuclear test [...] would represent a clear threat to international peace and security': UN SC 'Statement by the President of the Security Council': UN Doc. S/PRST/ 2006/41).

10 Michael Wood, 'The Interpretation of Security Council Resolutions' in: Armin von Bogdandy and Rüdiger Wolfrum (eds), Max Planck UNYB, Vol. 2 (Brill: Leiden 1998), 73-95.

11 Leland M. Goodrich and Anne Patricia Simons, The United Nations and the Maintenance of International Peace and Security (Washington: The Brookings Institution 1955), 234, argue 'the distinction is primarily a matter of the immediacy and seriousness of the danger to peace'. 
UN Charter is not conjunctive but disjunctive, referring to international peace or international security, since the intention is to protect each of these objects. In any case, the distinction between the two concepts of 'threat to the peace' and 'threat/endangerment to international peace and security' is first of all a political rather than a legal or factual question, ${ }^{12}$ since the Security Council has discretion to determine whether a situation is a 'threat to the peace' or a 'threat to international peace and security' (or to make no determination at all). ${ }^{13}$ Despite having different legal effects, the categories are 'not clearly defined'. ${ }^{14}$ The result is that the choice between the two labels is based on a potentially 'unpredictable and arbitrary' exercise of discretionary powers based on political considerations. ${ }^{15}$ The extent of the Council's discretion in this respect and its justiciability remain controversial. ${ }^{16}$ In any case, while overlapping (in the sense that all 'threats to the peace' are 'threats to international peace and security' while the reverse it not necessarily the case) and comprising discretionary categories, 'threats to the peace' and 'threats to international peace and security' are distinct legal categories under the UN Charter, ${ }^{17}$ giving rise to distinct legal consequences for the Council's functions and powers. It is therefore important to be precise in the analysis of Security Council resolutions and pay attention to whether they characterise a dispute or situation as a 'threat to the peace'

12 As Nigel White, Keeping the Peace: The United Nations and the Maintenance of International Peace and Security (Manchester: Manchester University Press 1997), 37, noted 'there is often no substantive factual distinction between the two. They are, in effect, often merely "labels" put into the resolutions to indicate the political climate in the Council.' See also ICTY, Prosecutor v. Dusco Tadic, Decision on the Defence Motion for Interlocutory Appeal on Jurisdiction (Appeals Chamber of 2 October 1995) ('Tadic case'), case no. IT-94-1-AR72, para. 29: "The situations justifying resort to the powers provided for in Chapter VII are a "threat to the peace", a "breach of the peace" or an "act of aggression". While the "act of aggression" is more amenable to a legal determination, the "threat to the peace" is more of a political concept. But the determination that there exists such a threat is not a totally unfettered discretion, as it has to remain, at the very least, within the limits of the Purposes and Principles of the Charter.'

13 Hans Kelsen The Law of the United Nations: A Critical Analysis of its Fundamental Problems (London: London Institute of World Affairs 1950), 26-27, argued that '[i]t is completely within the discretion of the Security Council to decide what constitutes a "threat to the peace"”.

14 Kenneth Manusama, The United Nations Security Council in the Post-Cold War Era: Applying the Principle of Legality (Leiden: Brill 2006), 50.

15 Manusama (n. 14), 50; Inger Österdahl, Threat to the Peace: The Interpretation by the Security Council of Article 39 of the UN Charter (Uppsala: Och Justus Forlag 1998), 103.

16 See De Wet (n. 9), 4, para. 16 for a discussion of both sides of the debate.

17 Original proposals for the drafting of the UN Charter linked the two concepts, empowering the Security Council to find a 'threat to the maintenance of international peace and security' if dispute resolution failed or was not complied with; this was dropped because it was seen as fettering the discretion of the Council: White (n. 12), 37. 
under Article 39, or as an endangerment of international peace and security in the sense of Article 24(1).

\section{Transnational Health Crises as Endangerments to Interna- tional Peace and Security}

The scale and global impact of the COVID-19 pandemic highlights the severity of the threat that phenomena and situations falling outside the traditional military security paradigm can pose to international peace and security. Already the COVID-19 pandemic (and the responses and reactions to it) has had an adverse impact on traditional security issues. Existing geopolitical tensions have been heightened and State-sponsored actors appear to be exploiting vulnerabilities created by the health crisis to intervene in other States and create destabilising effects by spreading coronavirus-related disinformation and carrying out cyber attacks. The pandemic has also lead to the deterioration of the humanitarian crisis in conflict settings such as in Yemen and served as a conflict multiplier by exacerbating indicators of violence such as unemployment, inequality, social stigma and distrust in public institutions. ${ }^{18}$ In Darfur, Sudan, the pandemic has led to delays in the completion of the Juba peace process, and concerns have been raised about increased risk of attacks by Al-Shabaab in Somalia to exploit the current situation. ${ }^{19}$ The UN Secretary-General identified key risks created by the COVID-19 pandemic, including further erosion of trust in public institutions through mismanagement or lack of transparency; major stressors caused by economic fallout, especially in fragile societies, less developed and transitioning countries; political tensions, and lack of legitimacy in relation to elections; in some conflict settings, increased incentives for some actors to exploit division, leading to escalation in violence; exploitation of the situation by terrorists to strike while attention is diverted to the pandemic; increased risk of bioterrorist attacks; international, regional, and national peace efforts are hindered and human rights challenges are being triggered or exacerbated by the pandemic. ${ }^{20}$

18 Germany's concept note for the high-level open debate of the Security Council on the theme 'Pandemics and security', to be held on 2 July 2020 at 10 a. m., UN Doc. S/2020/571, 23 June 2020, paras 3-6.

19 Secretary-General's remarks to the Security Council Open Video-Teleconference on the Maintenance of International Peace and Security: Implications of COVID-19 [as delivered], 2 July 2020, <www.un.org $>$.

20 Secretary-General's remarks to the Security Council on the COVID-19 Pandemic [as delivered], 9 April 2020, <www.un.org >. 
COVID-19 and other transnational health crises have thus far been determined by the Council implicitly or explicitly to be threats or endangerments to international peace and security and not 'threats to the peace' under Article 39 of the Charter. In Resolution 2532, the Security Council characterised the COVID-19 pandemic as 'likely to endanger the maintenance of international peace and security', and not as a 'threat to the peace' under Chapter VII. This wording exactly repeats the formulation in Article 33, which refers to 'any dispute, the continuance of which is likely to endanger the maintenance of international peace and security'. This characterisation of the COVID-19 pandemic indicates that the resolution was not adopted under Chapter VII (threat to the peace) but under Chapter VI of the Charter. The provision under which the resolution was adopted is discussed further below.

The three previous Security Council resolutions addressing transnational health crises also did not characterise those epidemics as 'threats to the peace' under Article 39. The Security Council has previously addressed transnational health crises in Resolution 1983 (2011) in response to the HIV/AIDS epidemic, ${ }^{21}$ as well as in response to Ebola outbreaks in West Africa in Resolution 2177 (2014) 22 and in the Democratic Republic of Congo (DRC) in Resolution 2439 (2018).23 In Resolution 1983 (2011), the Council did not mention a threat to the peace or threat to international peace and security, but referred to its primary responsibility for the maintenance of international peace and security. ${ }^{24}$ This implicitly characterises the HIV epidemic as a threat to international peace and security. The non-imperative language of the operative part of the resolution (underlines, notes, recognises, stresses, requests, encourages, welcomes, invites) further strongly suggests that the resolution was not adopted under Chapter VII. The two Security Council resolutions concerning Ebola differ in terms of their context and the Council's characterisation of the epidemic. Resolution 2177 concerned the Ebola outbreak in West Africa (Liberia, Guinea, Sierra Leone, Nigeria, Côte d'Ivoire, and Senegal) in 2014, whereas Resolution 2439 was in response to the Ebola outbreak in the DRC in 2018 during an ongoing situation of armed conflict and violence. In Resolution 2177 (2014), the Council '[r]ecall[ed] its primary responsibility for the maintenance of international peace and security'25 and 'determin[ed] that the unprecedented extent of the Ebola outbreak in Africa constitutes a threat to international peace and security'26 - not a

\footnotetext{
21 UN Doc. S/RES/1983 (2011).

22 UN Doc. S/RES/2177 (2014).

23 UN Doc. S/RES/2439 (2018).

24 UN Doc. S/RES/1983 (2011), Preambular para. 16.

25 UN Doc. S/RES/2177 (2014), Preambular para. 2.

26 UN Doc. S/RES/2177 (2014), Preambular para. 5.
} 
'threat to the peace'. ${ }^{27}$ In Resolution 2439 (2018), the Council did not directly recognise Ebola as a threat to international peace and security. Instead, the Council 'recall[ed] its determination in resolution 2409 (2018) that the situation in the DRC continues to constitute a threat to international peace and security in the region'. ${ }^{28}$

\section{The Scope of the Security Council's Mandate under Article 24(1)}

The fact that the Security Council either implicitly or explicitly characterised each of the epidemics (HIV/AIDS and the Ebola outbreaks in West Africa in 2014 and DRC in 2018) as well as the COVID-19 pandemic as threats to international peace and security or as likely to endanger the maintenance of international peace and security rather than as 'threats to the peace' under Article 39 relates to the scope of 'international peace and security' in Article 24(1) of the Charter. Despite the variation in wording, 'likely to endanger international peace and security' and 'threat to international peace and security' have the same meaning under the UN Charter29 and are thus both relevant to the scope of Article 24(1) (though the latter term is in addition of particular relevance to Chapter VI). Article 24(1) provides: 'In order to ensure prompt and effective action by the United Nations, its Members confer on the Security Council primary responsibility for the maintenance of international peace and security, and agree that in carrying out its duties under this responsibility the Security Council acts on their behalf.'

As the rest of this section will argue, Article 24(1) sets out the mandate (i. e. general competence) of the Security Council and, as explained further below, is also a source of binding decisions under Article 25. In his commentary on the UN Charter, Hans Kelsen canvassed the interpretive possibilities of Article 24(1), including that it 'may be interpreted to confer on the Security Council the competence to maintain peace by the means determined in Article 1,

27 Ilja Richard Pavone, 'Ebola and Securitization of Health: UN Security Council Resolution 2177/2014 and Its Limits' in: Leonie Vierck, Pedro A. Villarreal and A. Katarina Weilert (eds), The Governance of Disease Outbreaks (Baden-Baden: Nomos 2017), 301-326 (319), with further citations: 'Some scholars retain [...] that Resolution 2177 was adopted not within Chapter VII, but within Chapter VI of the UN Charter.'

28 UN Doc. S/RES/2409 (2018), Preambular para. 3, emphasis added.

29 Kelsen (n. 13), 362-363, noting the inconsistency of terms used throughout the Charter to 'characterise the dangerous character of disputes or other situations' including Article 1(1); $11(3) ; 14 ; 33(1) ; 34 ; 35(1) ; 36(1) ; 37(2)$ and concluding ' $[t]$ here is hardly any essential difference between the nature of the disputes and other situations characterised by the different formulas'. 
paragraph 1, of the Charter'. ${ }^{30}$ However, he also acknowledged the alternative possibility that it 'was intended only to stress the political importance of the Council, not to establish a positive legal effect'. ${ }^{31}$ This would suggest that Article 24(1) only sets out the general responsibilities of the Council, with the actual bases of competence contained in other Charter provisions such as Article 24(2). ${ }^{32}$ But Article 24(1) is not only a chapeau: it is the basis for the Security Council's legal mandate and confers general competence in addition to the specific powers set out in other Charter provisions. By referring to the discharge of 'duties', Article 24(1) implies that the Security Council is charged with these duties in the first place. Furthermore, an argument can be made $a$ contrario that Article 24(2) sets out 'the specific powers granted to the Security Council for the discharge of these duties' precisely because a general power is conferred in Article 24(1). This argument is strongly supported by the fact also acknowledged by Kelsen - that Article 24(2) is clearly not an exhaustive list of the Council's powers granted for this function. ${ }^{33}$

Article 24(1) itself also limits the action of the Security Council. The practice of the Council bears out the interpretation of Article 24(1) as placing a limit on what the Council may put on its agenda. Hence, with respect to some non-traditional security issues, Council members have disputed whether the item can be considered by the Council at all. This was the case for the HIV/AIDS epidemic, ${ }^{34}$ and more recently with respect to the climate crisis. ${ }^{35}$ By discussing matters in these terms, and also in its declarations that particular situations constitute a threat to international peace and security and in recalling in resolutions its primary responsibility for the maintenance of international peace and security, the Council is implicitly referring to the scope of its mandate set out in Article 24(1).

\section{General Powers Stemming from Article 24(1)}

It is important to consider the Security Council's overall mandate under Article 24(1) and not only the trigger for Chapter VII enforcement powers

30 Kelsen (n. 13), 283.

31 Kelsen (n. 13), 283.

32 Kelsen (n. 13), 283.

33 Kelsen (n. 13), 284; see also Anne Peters, 'Article 24' in: Bruno Simma, Daniel-Erasmus Khan, Georg Nolte, Andreas Paulus and Nikolai Wessendorf (eds), The Charter of the United Nations: A Commentary (3rd edn, Oxford: Oxford University Press 2012), 761-786, margin note 58 .

34 See Erika De Wet, The Chapter VII Powers of the United Nations Security Council (Oxford: Hart Publishing 2004), 172-174.

35 Benjamin Pohl and Hannah Elisabeth Kurnoth, Summary: UN SC Open Debate on Climate and Security, 24 July 2020. 
under Article 39, because Article 24(1) is a source of general express and implied powers of the Security Council, including the power to adopt binding decisions. There are three tiers or triggers for Security Council involvement which empower the Council to take certain types of measures. Its broadest sphere of competence is that set out in Article 24(1), namely, the maintenance of international peace and security. This is the argument just made above. The precondition for the exercise of this competence - an endangerment to international peace and security - is discussed further in the next section. The current part will focus on the powers conferred by Article 24(1) once this precondition arises. The second type of competence of the Security Council is enlivened once there is 'any dispute, or any situation which might lead to international friction or give rise to a dispute' ${ }^{36}$ In such cases, the Council may investigate 'in order to determine whether the continuance of the dispute or situation is likely to endanger the maintenance of international peace and security', ${ }^{37}$ or make recommendations under Article 36(1) (or under Articles 37 and 38 with respect to pacific settlement of disputes). Finally, the Security Council is empowered to take enforcement measures under Chapter VII once there is a threat to the peace, breach of the peace or act of aggression under Article 39. Such measures are only permissible under Chapter VII.

Resolution 2532 demonstrates the potential for the Council to make binding decisions outside Chapter VII to address new types of threats. Security Council resolutions (or parts of them) are binding when they constitute a 'decision' of the Council under Article 25. In its Namibia Advisory Opinion, the International Court of Justice (ICJ) held that decisions outside Chapter VII can also be binding. ${ }^{38}$ In terms of assessing the legal nature of a Security Council resolution, the ICJ held in the Namibia Advisory Opinion that:

'The language of a resolution of the Security Council should be carefully analysed before a conclusion can be made as to its binding effect. In view of the nature of the powers under Article 25, the question whether they have been in fact

36 UN Charter, Article 34.

37 UN Charter, Article 34.

38 Legal Consequences for States of the Continued Presence of South Africa in Namibia (South West Africa) notwithstanding Security Council Resolution 276 (1970) ("Namibia Advisory Opinion'), ICJ Reports 1971, 16, para. 113. For instance, Chapter VI resolutions can be binding. Rosalyn Higgins, 'The Advisory Opinion on Namibia: Which UN Resolutions Are Binding under Article 25 of the Charter?', ICLQ 21 (1972), 270-286; Anne Peters, 'Article 25' in: Bruno Simma, Daniel-Erasmus Khan, Georg Nolte, Andreas Paulus and Nikolai Wessendorf (eds), The Charter of the United Nations: A Commentary (3rd edn, Oxford: Oxford University Press 2012), 787-854, 794, margin notes 13 and 14; Theodor Schweisfurth, 'Article 34' in: Bruno Simma, Daniel-Erasmus Khan, Georg Nolte, Andreas Paulus and Nikolai Wessendorf (eds), The Charter of the United Nations: A Commentary (3rd edn, Oxford: Oxford University Press 2012), 1086-1107, margin note 42. 
exercised is to be determined in each case, having regard to the terms of the resolution to be interpreted, the discussions leading to it, the Charter provisions invoked and, in general, all circumstances that might assist in determining the legal consequences of the resolution of the Security Council.'39

It is possible though unclear whether the measures called for in Resolution 2532, namely, the demand for a global ceasefire and humanitarian pause, are legally binding. ${ }^{40} \mathrm{It}$ is likely that they were enacted either under Article 36 of the Charter and are therefore non-binding 'recommendations' under that provision ${ }^{41}$ or under Article 24(1) itself in combination with its implied powers.

In addition to the express powers granted by the Charter, particularly under Chapters VI and VII, the Security Council also has implied powers stemming from its general responsibilities under Article 24(1). Such powers may extend beyond its Chapter VI investigative and recommendatory powers, but do not encompass the enforcement action foreseen in Articles 41 and 42. Limits to the Council's powers are discussed in Section III below. According to this argument, the Security Council has implied powers which derive solely from Article 24(1) and may be binding 'decisions' under Article 25 because, as noted above, Article 24(2) is not an exhaustive list of Security Council powers in exercising its functions. As the ICJ held in its Reparations for Injuries Advisory Opinion: 'Under international law, the Organisation must be deemed to have those powers which, though not expressly provided in the Charter, are conferred upon it by necessary implication as being essential to the performance of its duties.' ${ }^{42}$ This was applied by the ICJ in the Namibia Advisory Opinion with respect to the Security Council, when it held that '[a]rticle 24 of the Charter vests in the Security Council the necessary authority to take action such as that taken in the present case. The reference in paragraph 2 of this Article to express powers of the Security Council under certain chapters of the Charter does not exclude the existence of implied powers to discharge the responsibilities conferred in paragraph $1 .{ }^{43}$

39 Namibia Advisory Opinion (n. 38), para. 114.

40 See Erin Pobjie, 'Covid-19 as a Threat to International Peace and Security: The Role of the UN Security Council in Addressing the Pandemic', 27 July 2020, <www.ejiltalk.org>.

41 Thomas Giegerich, 'Article 36' in: Bruno Simma, Daniel-Erasmus Khan, Georg Nolte, Andreas Paulus and Nikolai Wessendorf (eds), The Charter of the United Nations: A Commentary (3rd edn, Oxford: Oxford University Press 2012), 1119-1145 (1145), margin note 76: 'In subsequent practice States have repeatedly emphasized the non-binding character of the SC recommendations under Art. 36.'

4213 July 1954, ICJ Reports 1954, at 47.

43 Namibia Advisory Opinion (n. 38), para. 110. 
As Thomas Giegerich explains, this means that the Security Council may act under its express powers set out in Article 24(2) or under implied powers under Article 24(1).44 'It also explains the considerable number of resolutions which were not adopted under Chapter VII and obviously concern either "disputes" or "situations" in the sense of Art. 36 (1), but which neither recommend any method of settlement, as foreseen in the latter provision, nor any terms of settlement pursuant to Art. 37 (2) or Art. 38. The legal basis of those resolutions can only be the general power of the SC flowing from Art. 24 (1).' 45 Nigel White argues that 'the Western insistence that only Chapter VII resolutions are binding has resulted in an artificial approach to the Charter', and that many resolutions presumed to be under Chapter VII, including the resolutions dealing with the Iraqi invasion of Kuwait ${ }^{46}$ and the establishment of the International Criminal Tribunals for the Former Yugoslavia and Rwanda respectively 47 'are really examples of the Council's general powers to maintain and restore international peace and security derived from Article 24 which are clearly intended to be binding by Article $25^{\prime} .^{48}$ In the same way, the demand for a global ceasefire in Resolution 2532 could also be an example of the exercise of the Council's general and implied powers to maintain international peace and security provided by Article 24(1) and binding under Article 25. This highlights the practical importance of understanding the scope of its mandate under Article 24(1) and not only with respect to 'threats to the peace' under Article 39.

\section{Conclusion}

The Security Council has thus far characterised all transnational health crises it has dealt with, including the COVID-19 pandemic, as threats to/ endangerment of international peace and security under Article 24(1) and not 'threats to the peace' under Article 39. The previous focus on traditional security threats and corresponding coercive measures under Chapter VII resulted in scholars focusing their attention on Article 39 'threat to the peace'. However, it is Article 24(1) that sets out the mandate of the Security Council, providing that it has primary responsibility for the maintenance of international peace and security. Therefore, this practice of the Council affects the

\footnotetext{
44 Giegerich (n. 41), 1123, margin note 13.

45 Giegerich (n. 41), 1123-1124, margin note 9, footnotes omitted.

46 Namely, UN SC Res. 664 (1990), 667 (1990), 674 (1990), 677 (1990) and 687 (1990).

47 UN SC Res. 827 (1993) and 955 (1994).

48 White (n. 12), 63, footnotes omitted.
} 
interpretation of Article 24(1) and accordingly, the scope of its mandate. As this section has argued, the Council's general express and implied powers under Article 24(1) may include the power to issue binding (though noncoercive) legal acts, even in situations which are not a 'threat to the peace' under Article 39, to address situations which endanger the maintenance of international peace and security. It is therefore important to pay attention to the scope of Article 24(1).

\section{Interpretation of 'International Peace and Security' in Article 24(1)}

Resolution 2532 consolidates a trend towards a broader, human securitybased interpretation of 'international peace and security' in the UN Charter. This correspondingly broadens the mandate of the Security Council under Article 24(1) (the implications of which are addressed further in Section IV). The following section discusses the original intended meaning of this term in the Charter, argues that an evolutionary interpretation is to be preferred, and that the practice of the Council in interpreting its own mandate is relevant 'practice' for this purpose. It then demonstrates that this practice - including the resolutions on transnational health crises - indicates a limited evolution in interpretation from the original meaning of military threats, to a broader understanding which mirrors a corresponding expansion in the understanding of 'threat to the peace' under Article 39.

\section{UN Charter Interpretation}

As a multilateral treaty, the UN Charter is subject to the general law of treaty interpretation. ${ }^{49}$ This is likely to be a rule of customary international law, ${ }^{50}$ as confirmed by the approach of the ICJ..${ }^{51}$ The general rules of treaty

491969 Vienna Convention on the Law of Treaties, 1155 UNTS 331, Art. 5.

50 Georg Nolte, 'Third Report on Subsequent Agreements and Subsequent Practice in Relation to the Interpretation of Treaties', A/CN.4/683, International Law Commission, 7 April 2015, 32-33, paras 83-85; See also Georg Witschel, 'Article 108' in: Bruno Simma, DanielErasmus Khan, Georg Nolte, Andreas Paulus and Nikolai Wessendorf (eds), The Charter of the United Nations: A Commentary (3rd edn, Oxford: Oxford University Press 2012), 2199, 2204, margin note 8 .

51 ICJ, Legality of the Threat or Use of Nuclear Weapons, Advisory Opinion, ICJ Reports 1996, 226, para. 19, also with respect to the UN Charter: ICJ, Certain Expenses of the United Nations (Article 17, paragraph 2 of the Charter), Advisory Opinion, ICJ Reports 1962, 151, 157. 
interpretation are laid out in Articles 31 and 32 of the Vienna Convention on the Law of Treaties (VCLT), which are applicable to the UN Charter as customary rules. ${ }^{52}$ According to Article 31(1), '[a] treaty shall be interpreted in good faith in accordance with the ordinary meaning to be given to the terms of the treaty in their context and in the light of its object and purpose'. In 1951, Kelsen noted that '[i]n ordinary use of language "international peace" is a condition of absence of force in the relations among states'. ${ }^{53}$

However, because of the Charter's unique nature as a constituent instrument of an international organisation, an evolutive interpretation is to be preferred over a static interpretation emphasising the original meaning of the terms used or the drafters' intentions. According to the ICJ in the Legality of the Use by a State of Nuclear Weapons in Armed Conflict Advisory Opinion, such constitutional treaties have a hybrid nature which need a dynamic (evolutive) interpretation. ${ }^{54} \mathrm{~A}$ dynamic approach to the interpretation of Article 24(1) is further supported by the use of a term which is very general and 'whose meaning is inherently more context-dependent', as it indicates an intention of the parties at the time of concluding the treaty that the interpretation change over time. ${ }^{55}$ The term 'international peace and security' in Article 24(1) is general and context-dependent and its interpretation will change according to new types of threats which emerge, including due to technological advances or threats of a nature that were unforeseen at the time of drafting the Charter.

52 International Law Commission, Draft Conclusions on Subsequent Agreements and Subsequent Practice in Relation to the Interpretation of Treaties, with Commentaries, adopted by the ILC at its seventieth session, (2018), ILCYB 2018, Vol. II, Part 2, conclusion 2(1).

53 Kelsen (n. 13), 19; see also Manusama (n. 14), 32, footnotes omitted: 'If looked upon from a historical perspective, the phrase "international peace and security" was usually linked with the presence or absence of war or armed conflict between states, not with internal disorder. In this sense, "peace" denotes the absence of inter-state armed conflict, or "negative peace", and "security" denotes "the activity which is necessary for maintaining the conditions of peace", or "positive peace".'

54 ICJ Reports 1996, 66, para. 19; see also Thilo Rensmann, 'Reform' in: Bruno Simma, Daniel-Erasmus Khan, Georg Nolte, Andreas Paulus and Nikolai Wessendorf (eds), The Charter of the United Nations: A Commentary (3rd edn, Oxford: Oxford University Press 2012), 31-32, margin note 20, footnotes omitted: 'The practical quality of the UN Charter as the constitution of the UN and the international community at large provides additional support for considering the Charter to be a "living instrument" which must be "capable of growth and development over time to meet new social, political and historical realities often unimagined by its framers".'

55 Georg Nolte, 'First Report on Subsequent Agreements and Subsequent Practice in Relation to Treaty Interpretation', International Law Commission, 19 March 2013, 26, paras 56 and 61. 


\section{Security Council Resolutions as 'Subsequent Practice'}

Furthermore, 'as the Security Council is charged with maintaining and restoring international peace and security [...] [i]t is the extent of the Council's practice that must determine what constitutes international peace and security'. ${ }^{56}$ As an organ of the United Nations, the Council's practice in interpreting and applying Article 24(1) is a 'relevant means of interpretation' under the VCLT, although the precise legal basis for this remains debated among legal scholars. ${ }^{57}$ According to the International Law Commission, '[ $\mathrm{t}$ ] he possible relevance of an international organisation's "own practice" can [...] be derived from Articles 31 and 32 of the 1969 Vienna Convention. 58 The jurisprudence of the ICJ shows that practice of organs of the United Nations such as the Security Council in the application of the Charter may be relevant as a form of other subsequent practice under Article 32 of the VCLT (i.e. as a supplementary means of interpretation), independently of the practice or acceptance of all parties to the UN Charter. ${ }^{59}$ Such resolutions will carry more weight when they deal with an area for which the burden of obligation falls on those bodies, such as the Council's practice in determining its own jurisdiction under Article 24(1): as the ICJ held in the Certain Expenses Advisory Opinion, '[a]s anticipated in 1945 [...] each organ must, in the first place at least, determine its own jurisdiction'. 60

Furthermore, when a UN Security Council resolution is adopted without dissenting votes and is accompanied by the general acceptance of UN Member States, this may be considered as potentially relevant subsequent practice under Article 31(3)(b) of the VCLT. Georg Nolte observes that the ICJ applied this approach in its Namibia Advisory Opinion, where the Court interpreted the term 'concurring votes' in Article 27(3) of the UN Charter as including voluntary abstentions 'primarily by relying on the practice of the organ concerned in combination with the fact that it was then "generally accepted" by member States'. ${ }^{61}$ Nolte notes that “" $[\mathrm{g}]$ eneral acceptance" requires "at a minimum” acquiescence'. 62 Inger Österdahl argues that Security Council resolutions are relevant subsequent practice under Article 31(3)(b)

56 Manusama, (n. 14), 32.

57 International Law Commission, Draft Conclusions with Commentaries (2018) (n. 52), Commentary to Conclusion 12, para. 32.

58 International Law Commission, Draft Conclusions with Commentaries (2018) (n. 52),

Commentary to Conclusion 12, para. 34.

59 Nolte, Third Report (n. 50), 16-19, paras 43-51.

60 Vienna Convention on the Law of Treaties (n. 49), 168.

61 Nolte, Third Report (n. 50), 19, para. 52.

62 Nolte, Third Report (n. 50), 30, para. 80, footnote omitted. 
even if the resolutions are not unanimous, since all Members of the UN consent to this system of decision-making under the Charter. ${ }^{63}$

The Security Council thus has a wide discretion to shape the interpretation of the scope of its own powers through its practice. However, such discretion is not unlimited; although it is a political body it is not outside the law. ${ }^{64}$ Limits to its powers include those explicitly set out in the UN Charter itself, such as the domestic jurisdiction clause in Article 2(7), ${ }^{65}$ Article 24(2) ('[i]n discharging these duties the Security Council shall act in accordance with the Purposes and Principles of the United Nations') and Article 25 ('in accordance with the present Charter'). ${ }^{66}$ Further limitations that have been suggested include jus $\operatorname{cogens}^{67}$ and the requirements of good faith and doctrine of abuse of power. ${ }^{68}$ However, in practical terms, it is unclear what the legal effect of an ultra vires decision by the Council would be and if this could be directly adjudicated. ${ }^{69}$

\section{Evolution of the Interpretation of 'International Peace and Security'}

As argued above, the Security Council's mandate is set out in Article 24(1) and a determination that a matter falls within this ambit (because it is a threat

63 Österdahl (n. 15), 91.

64 ICTY, Tadic (n. 12), para. 28: 'neither the text nor the spirit of the Charter conceives of the Security Council as legibus solutus (unbound by law)'; Peters (n. 33), 771, margin note 29; Manusama (n. 14), 45; Robert Cryer, 'The Security Council and Article 39: A Threat to Coherence?', Journal of Armed Conflict Law 1 (1996) 1, 161-195, (167-168).

65 Manusama (n. 14), 33; cf. Cryer (n. 64), 170.

66 Cryer (n. 64), 167-168.

67 Separate Opinion of Judge Lauterpacht, ICJ, Bosnian Genocide Case, Provisional Measures, Order of 13 September 1993, ICJ Reports 1993, 325 (440), para. 100: 'one only has to state the opposite proposition thus - that a Security Council resolution may even require participation in genocide - for its unacceptability to be apparent.'; Cryer (n. 64), 170; Österdahl (n. 15), 91: jus cogens seems to be the 'only legal limit really on the freedom of interpretation and of action in particular of the Security Council'.

68 Cryer (n. 64), 169, although he points out it is hard to prove bad faith. See also Manusama (n. 14), 45: 'The limits consist of sovereignty and its corollaries: the sovereign equality of states, the domestic jurisdiction clause of Article 2(7) and the obligation to perform its functions and exercise its powers in good faith. Moreover, ius cogens norms and erga omnes obligations, as well as human rights and international humanitarian law, are incumbent on the Security Council.'

69 See White (n. 12), 67-73; Pemmaraj Sreenivasa Rao, 'An Indian Perspective' in: Christian Tomuschat (ed.), The United Nations at Age Fifty: A Legal Perspective (Leiden: Brill 1995), 143-184 (179); Peters (n. 33), 771, margin notes 29-30. De Wet (n. 34), 129 and 382 concludes that the ICJ has a limited role in judicial review of Security Council decisions and proposes a unilateral right of States as a last resort to reject illegal Security Council resolutions. 
or endangerment to international peace and security) means it forms part of the Council's practice in interpreting its mandate. This practice has evolved in response to new types of threats which emerged after the end of the Cold War from less predictable and disparate sources, including non-State armed groups. ${ }^{70}$ The ideological foundation of this trend was arguably the Security Council Presidential Statement of 31 January 1992,71 in which for the first time a UN body gave the term 'international peace and security' a broad meaning extending beyond war and military conflicts. ${ }^{72}$ It stated: '[ $\left.t\right]$ he absence of war and military conflicts among States does not in itself ensure international peace and security. The non-military sources of instability in the economic, social, humanitarian and ecological fields have become threats to peace and security. ${ }^{73}$ The previous year, the Council had passed Resolution 688 characterising massive cross-border refugee flows of Kurds from Northern Iraq as a threat to international peace and security. In 1992, this was followed by Resolution 794 authorising US intervention in Somalia in which the Council characterised 'the magnitude of the human tragedy caused by the conflict in Somalia' as a 'threat to international peace and security'. ${ }^{74}$ Resolution 965 (1994) on Rwanda ${ }^{75}$ and Resolution 1529 (2004) on Haiti' followed. In 2019, the Council adopted two resolutions addressing wildlife poaching and trafficking as a factor threatening peace in Central African Republic $^{77}$ and the Democratic Republic of Congo ${ }^{78}$ respectively. From 2001, the Security Council characterised abstract phenomenon as threats to international peace and security, including international terrorism, the proliferation of nuclear weapons and other weapons of mass destruction, epidemics and pandemics. ${ }^{79}$ Christian Tomuschat's interpretation of Article 33(1) in the third edition of The Charter of the United Nations: A Commentary (2012) reflects this change, stating that the narrow interpretation set out in the previous edition that 'the criterion of international peace and security' refers only to negative peace 'must be abandoned'..$^{80}$

70 Pavone (n. 27), 304.

71 UN Doc. S/23500, Decision of 31 January 1992 (3046th meeting), Statement by the President.

72 Pavone (n. 27), footnote omitted; Peters (n. 33), 772, margin note 34.

73 UN Doc. $S / 23500$ (n. 71), 3.

74 UN Doc. S/RES/794 (1992), Preambular para. 3.

75 UN Doc. S/RES/965 (1994).

76 UN Doc. S/RES/1529 (2004).

77 UN Doc. S/RES/2499 (2019), Preambular paras 11 and 41.

78 UN Doc. S/RES/Res. 2502 (2019), paras. 16 and 45.

79 De Wet (n. 9), 3, para. 9.

80 Christian Tomuschat, 'Article 33' in: Bruno Simma, Daniel-Erasmus Khan, Georg Nolte, Andreas Paulus and Nikolai Wessendorf (eds), The Charter of the United Nations: A Commentary (3rd edn, Oxford: Oxford University Press 2012), 1069-85, margin note 13. 
This evolution in the interpretation of 'threat to international peace and security' is consistent with the concomitant well-known expansion in the interpretation of 'threat to the peace' under Article 39.81 Originally used in the sense of military threats mainly involving cross-border uses of armed force, the concept of 'threat to the peace' has evolved over time, beginning by the late $1960 \mathrm{~s}$ (with the resolution on Southern Rhodesia ${ }^{82}$ ) to include a more positive conception of peace, such as respect for human rights. ${ }^{83}$ This change has also included a move away from security threats with transboundary effects to include internal situations because of their negative impact on the protected object of international peace in the sense of 'more positive aspects of common interests of humanity, there being a threat to the peace if there are violations of these interests, irrespective of where they occur'. ${ }^{84}$ An alternative view is that the Council characterises some internal crises as a 'threat to the peace' because of the threat of spillover effects affecting traditional security interests. ${ }^{85}$ This raises similar questions as with the interpretation of 'threat to international peace and security' in the Security Council's practice, namely, whether the Council is tending toward a conception of positive peace (protection of human security), ${ }^{86}$ or if it is rather an expansion in the origin and scope of potential threats to traditional security interests (negative peace, but with a broader causal outlook).

81 See White (n. 12) for a good discussion of the evolution of the concept of 'threats to the peace' in Council practice, 42. As with the scope of the Council's general mandate, the limits to its discretion in interpreting when there is a 'threat to the peace' empowering it to demand enforcement measures remains debated: De Wet (n. 9), 5, para. 23.

82 UN Doc. S/RES/216 (1965).

83 Cryer (n. 64), 187.

84 Cryer (n. 64), 188.

85 See, e. g., Michael J. Matheson, Council Unbound - The Growth of UN Decision Making on Conflict and Postconflict Issues after the Cold War (Cambridge: Cambridge University Press 2006), 46, who notes that the Council has characterised internal crises as threats to the peace 'where there was a plausible concern that their continuation might lead to international conflict or destabilize neighbouring countries'. See also Anne Peters, 'Novel practice of the Security Council: Wildlife poaching and trafficking as a threat to the peace', 12 February 2014, $<$ www.ejiltalk.org>: 'Overall, the Charter's expanded and "positive" notion of peace does not seem to be devoid of any transboundary element yet.'

86 The UNDP's 1994 Human Development Report defined human security as 'safety from chronic threats, hunger, disease and repression' and 'protection from sudden and hurtful disruption in the patterns of daily life'. This understanding of human security draws on the distinction between negative and positive peace developed by Johan Galtung, 'An Editorial', Journal of Peace Research 1 (1964), 1 and the notion of sustainable human development, including the works of Amartya Sen, and reflects a move away from a conventional military understanding of threats and response: see Pavone (n. 27), 312-313. See also Hitoshi Nasu, 'The Place of Human Security in Collective Security', Journal of Conflict and Security Law 18 (2013), 95-129 (97-100) for an explanation of the concept of human security and how it relates to securitisation. 


\section{Security Council Practice Addressing Transnational Health Crises}

Security Council resolutions addressing transnational health crises (namely, 1983, 2177, 2439, and 2532) align with this broader trend towards expanding the interpretation of 'international peace and security' under Article 24(1). This is shown by the factors the Council chose to emphasise when characterising the respective situations (either implicitly or explicitly) as threats or endangerments to international peace and security. Over the course of these precedents, the Council has demonstrated increasing confidence in its legal competence to deal with global public health, but at the same time, continued to emphasise the links between global public health and traditional threats to international peace and security. The result is a progressive (though limited) development in the Council's interpretation of its mandate to maintain international peace and security.

In the lead up to the adoption of an earlier resolution 1308 (17 July 2000), for the first time the Security Council debated a health issue - the HIV/AIDS epidemic - in the context of international peace and security. ${ }^{87}$ Some scholars argued that this was outside the scope of the Council's mandate. ${ }^{88}$ Resolution 1308 (2000) seems to confirm scepticism about whether the epidemic as such fell within the scope of the Council's mandate, focusing as it did on the 'potential damaging impact of HIV/AIDS on the health of international peacekeeping personnel, including support personnel'. ${ }^{89}$ But in 2011, the Security Council adopted Resolution 1983 dealing with the HIV/AIDS epidemic, thus confirming through its practice the interpretation that the matter fell within the scope of its mandate. In that second resolution, the Security Council emphasised several factors, including the high numbers of infections and deaths (at that time, over 60 million and 25 million respectively), ${ }^{90}$ the challenges that HIV poses 'to the development, progress and stability of societies'91 and the two-way relationship between the epidemic and situations of conflict. ${ }^{92}$ Of these, the Council placed the most emphasis on the latter, '[r]ecognizing that the spread of HIV can have a uniquely devastating impact on all sectors and levels of society, and that in conflict and post-conflict situations, these impacts may be felt more profoundly', ${ }^{93}$ and

\footnotetext{
87 De Wet (n. 9), 4, para. 13.

88 E.g. Manusama (n. 14), 3.

89 UN Doc. S/RES/1308 (2000), para. 1.

90 Resolution 1983 (2011), Preambular para. 1.

91 Resolution 1983 (2011), Preambular para. 6.

92 Resolution 1983 (2011), Preambular para. 10.

93 Resolution 1983 (2011), Preambular para. 9.
} 
that in turn, 'conditions of violence and instability in conflict and postconflict situations can exacerbate the HIV epidemic, inter alia, through large movements of people, widespread uncertainty over conditions, conflict-related sexual violence, and reduced access to medical care'. ${ }^{94}$ The Security Council also recognised 'the continuing negative impact of HIV on the health and fitness of UN missions personnel'. ${ }^{95}$ The measures requested by the Council further emphasise the connection between HIV and conflict and peace-building, requesting the Secretary-General to take the impact of HIV into consideration in his roles relating to conflict and peace-building ${ }^{96}$ and focusing on incorporating HIV prevention, treatment and care into peacekeeping operations and preventing HIV transmission within UN missions. ${ }^{97}$ This temerity in essentially confining the measures to peace-building missions reflects the gravity of the health situation within UN missions at that time, ${ }^{98}$ but may also reflect early hesitations about whether transnational health crises fell into the Council's mandate in the first place.

By 2014, this understanding of the Council's mandate had progressed and the next Security Council resolution concerning a transnational health crisis (the Ebola outbreak in West Africa) was adopted by consensus and supported by an astounding $130 \mathrm{UN}$ member States. ${ }^{99}$ In Resolution 2177, the Security Council again '[r]ecogniz[ed] that the peacebuilding and development gains of the most affected countries concerned could be reversed in light of the Ebola outbreak and underlin[ed] that the outbreak is undermining the stability of the most affected countries concerned and, unless contained, may lead to further instances of civil unrest, social tensions and a deterioration of the political and security climate'. ${ }^{100}$ In the resolution, the Council referred to 'global public health security'101 as well as the impact of the Ebola outbreak and travel and trade restrictions in response to it on 'food security'102 and '[e]ncourage[d] the governments of Liberia, Sierra Leone and Guinea to continue efforts to resolve and mitigate the wider political, security, socioeconomic and humanitarian dimensions of the Ebola outbreak [...]. ${ }^{103}$ This

94 Resolution 1983 (2011), Preambular para. 10.

95 Resolution 1983 (2011), para. 1.

96 Resolution 1983 (2011), paras 6 and 7.

97 Resolution 1983 (2011), paras 8 and 9.

98 '[A]vailable statistics indicate that health-related issues have become a leading cause of fatality in the field since 2000', Preambular para. 14.

99 See Statement by the President of the Security Council of 21 November 2014, UN Doc. S/PRST/2014/24.

100 UN Doc. S/RES/2177 (2014), Preambular para. 4.

101 UN Doc. S/RES/2177 (2014), Preambular para. 5.

102 UN Doc. S/RES/2177 (2014), Preambular paras 17 and 22.

103 UN Doc. S/RES/2177 (2014), para. 2. 
evidences the Council's broadening understanding of the scope of its own mandate and the concept of international peace and security. By 'call[ing] on' States to lift travel and border restrictions, ${ }^{104}$ facilitate delivery of assistance including personnel and supplies, ${ }^{105}$ enhance communication efforts, ${ }^{106}$ and provide urgent resources and assistance including deployable medical capabilities, ${ }^{107}$ the Council also took more concrete and assertive steps in response to the epidemic beyond traditional coercive measures or those focused on peacekeeping. However, as Ilja Richard Pavone argues, in Resolution 2177, 'the Security Council did not directly address the disease and its implications for the health of the populations affected, but rather its political consequences in terms of possible civil unrests and riots that could have led to the collapse of the fragile political institutions in the hardest hit countries'. ${ }^{108}$

In its next global health resolution 2439 (2018), the Council expressed 'serious concern regarding the security situation in the areas affected by the Ebola outbreak, which is severely hampering the response efforts and facilitating the spread of the virus in the DRC and the wider region' ${ }^{109}$ and called for the 'immediate cessation of hostilities by all armed groups, including the Allied Democratic Forces (ADF)'. The factors that the Security Council mentioned as well as the measures adopted indicate that unlike Resolution 2177 (2014), Resolution 2439 (2018) was concerned with the context of the conflict in the DRC and not directly the Ebola outbreak as such. The Council '[e]xpress[ed] grave concern about the most recent outbreak of the Ebola virus in the Democratic Republic of Congo (DRC) and the fact that this epidemic is occurring in the context of much wider humanitarian needs, in a country whose people have suffered from the recurrence of the disease, armed conflict and violence for the last few decades', ${ }^{110}$ 'concern that this security situation negatively impacts the ability to respond to and contain the outbreak of the Ebola virus'111 and '[u]nderscor[ed] the need to address the security situation in the areas affected by the disease [...]'. ${ }^{112}$ In the first operative paragraph of the resolution, the Security Council ' $[r]$ eiterates its deep concern regarding the overall security and humanitarian situation in the DRC, exacerbated by destabilising activities of foreign and domestic armed

\footnotetext{
104 UN Doc. S/RES/2177 (2014), para. 4.

105 UN Doc. S/RES/2177 (2014), para. 5.

106 UN Doc. S/RES/2177 (2014), para. 6.

107 UN Doc. S/RES/2177 (2014), para. 7,

108 Pavone (n. 27), 322, footnote omitted.

109 UN Doc. S/RES/2439 (2018), para. 4.

110 Resolution 2177 (2014), Preambular para. 1.

111 Resolution 2177 (2014), Preambular para. 3.

112 Resolution 2177 (2014), Preambular para. 9.
} 
groups $[\ldots]$ '. ${ }^{113}$ As the resolution makes clear, this security situation included 'acts of violence, attacks and threats intentionally directed against medical personnel and humanitarian personnel exclusively engaged in medical duties [...]'. ${ }^{114}$ As in the previous Ebola resolution, the Council refers to 'global public health security' and 'public health threats'. ${ }^{115}$

In the preamble to its most recent global health resolution, Resolution 2532 (2020), the Security Council emphasised 'the devastating impact of the COVID-19 pandemic across the world, especially in countries ravaged by armed conflicts, or in post-conflict situations, or affected by humanitarian crises', 116 'that conditions of violence and instability in conflict situations can exacerbate the pandemic, and that inversely the pandemic can exacerbate the adverse humanitarian impact of conflict situations', 117 and 'that the peacebuilding and development gains made by countries in transition and post-conflict countries could be reversed in light of the COVID-19 pandemic outbreak'. ${ }^{118}$ In doing so, the Security Council appears to place importance on the impact of the pandemic in conflict and post-conflict situations, and the mutual relationship between the pandemic and conditions of violence and instability in conflict situations. Thus, it seems that the Security Council characterised the pandemic as likely to endanger international peace and security mainly because of its impacts on traditional peace and security matters such as situations of armed conflict as well as on fragile situations of post-conflict and humanitarian crises which may worsen and destabilise into violence.

\section{Conclusion}

We can thus distinguish several differences in the Security Council's characterisation of these transnational health threats, namely, when the Council considers the disease itself to be a threat to international peace and security, as in Resolution 2177 (2014) (the Ebola outbreak in West Africa), and when the effects of the disease in pre-existing situations of armed conflict are decisive to its characterisation, such as Resolution 2439 (2018) (the Ebola outbreak in DRC). ${ }^{119}$ Resolution 2532 appears to fall into the latter category

\footnotetext{
113 Resolution 2177 (2014), para. 1.

114 Resolution 2177 (2014), Preambular para. 11.

115 Resolution 2177 (2014), Preambular para. 12.

116 UN Doc. S/RES/2532 (2020), Preambular para. 3.

117 UN Doc. S/RES/2532 (2020), Preambular para. 4.

118 UN Doc. S/RES/2532 (2020), Preambular para. 5.

119 Pedro A. Villarreal, 'The Security Council and Covid-19: Towards a Medicalization of International Peace and Security', ESIL Reflection 9 (2021).
} 
and also bears further similarities to Resolution 2439 in terms of measures called for, including most notably a ceasefire. Furthermore, each of these four key resolutions marks a broader and more assertive response by the Security Council to transnational health crises. However, in light of the relatively mixed practice, these conclusions must be expressed cautiously. ${ }^{120}$

Resolution 2532 appears to continue a trend towards a broader concept of international peace and security beyond conventional security threats. On the other hand, by emphasising the links between the pandemic and situations of conflict, post-conflict, and humanitarian crisis, and by focusing its measures mostly on armed conflicts in situations on its agenda (paras 1 and 2), it rows back on the high point of this trend which seemed to be reached with Resolution 2177. The overall tendency towards broadening the concept of international peace and security now seems clearer with this fourth important Security Council resolution addressing a transnational health crisis, since the narrowing of the concept in the previous Resolution 2439 through its emphasis on the military security aspect could be explained by the specific context in which that outbreak occurred. On the other hand, Resolution 2532 indicates a trend in the practice of the Council towards a narrower form of this broader concept of human security which continues to recognise nonmilitary factors that may negatively affect international peace and security in a sense more restricted to armed conflict and violence. The focus on military factors may also reflect the limited consensus possible in the context of a strained geopolitical situation among the permanent members of the Council and disagreement over how to address the pandemic. In any case, it remains open to the Council to adopt further resolutions on this pandemic or other transnational health crises (or indeed, other non-traditional security threats) which conform to the broader interpretation indicated in previous resolutions.

\section{Implications}

The remainder of this article briefly discusses the broader implications and pros and cons of a more expansive scope of Security Council competence to address non-traditional security threats, focusing on its response to the

120 Nasu (n. 86), 97 also concludes that 'UN Member States are in general agreement on accommodating the narrow conception of human security within the Security Council's mandate and have progressively supported the wider conception to inform the exercise of its mandate, which diverging on how the Security Council should approach human security issues'. 
COVID-19 pandemic in particular. Risks include increasing securitisation and possible militarisation of the health crisis, stepping on mandates of other bodies such as the WHO, inappropriateness of Chapter VII coercive measures to respond to complex crises of this nature and a perceived lack of legitimacy. On the other hand, the present crisis reveals an opportunity to reframe and reconceptualise collective security and the Security Council's role in confronting new global challenges.

\section{Risk of Securitisation of Global Health}

The securitisation of global health has been subject to extensive critical analysis, particularly with regard to the exceptional or emergency powers it is often used to justify. ${ }^{121}$ As the securitisation of particular situations is also shaped by subjective factors (since what is considered a threat is in the eye of the observer), ${ }^{122}$ this results in potential arbitrariness as to which situations are treated as security threats and which are not. ${ }^{123}$ However, this does not differ from other situations characterised as threats to international peace and security, since this is a discretionary decision of the Security Council which is not necessarily based on empirical assessments. ${ }^{124}$ As has already been observed at the national level, securitisation of a disease may also lead to 'draconian emergency responses which are ineffective, counterproductive and/or unjust'. ${ }^{125}$ It can also lead to a militarisation of the response rather than framing an epidemic or pandemic as a humanitarian or health issue, ${ }^{126}$

121 See, e. g., Tim Hanrieder and Christian Kreuder-Sonnen, 'WHO Decides on the Exception? Securitization and Emergency Governance in Global Health', Security Dialogue, Vol. 45 (2014), 331-348; Colin McInnes and Simon Rushton, 'HIV, AIDS and Security: Where are We Now?' International Affairs 86 (2010), 225-245; Clare Wenham, 'The Oversecuritization of Global Health: Changing the Terms of Debate', International Affairs 95 (2019), 1093-1110.

122 The theory of securitisation is based on the work of Barry Buzan, Ole Wrever and Jaap de Wilde, Security: A New Framework for Analysis (Boulder Colorado: Lynne Rienner Publishers 1998). See also Hitoshi Nasu, 'The Expanded Conception of Security and International Law: Challenges to the UN Collective Security System Scientific Article', Amsterdam Law Forum 3 (2011), 15-33, applying this theory to different spheres of national and international security.

123 See Michael J. Selgelid and Christian Enemark, 'Infectious Diseases, Security and Ethics: The Case of HIV/AIDS', Bioethics 22 (2008), 457-465 (459) for an interesting analysis of why certain diseases and not others are securitised.

124 'Empirically, it is virtually impossible to give a general answer to the question of what kinds of situations, apart of course from obvious direct military threats or attacks, really do threaten international peace and security.' Österdahl (n. 15), 86.

125 Selgelid and Enemark (n. 123), 461.

126 Pavone (n. 27), 314. 
with attendant human rights impacts. Placing it within the mandate of a political body such as the UN Security Council to determine whether particular infectious diseases constitute a security threat moves the response away from global health experts and risks politicisation and militarisation. ${ }^{127}$

\section{Potential for Global Coordination of Response}

The benefits of the Security Council taking the decision to characterise a pandemic as a threat to international peace and security are that it 'may also raise the political profile of the situation at hand, generating political commitment, mobilising additional financial resources and facilitating the deployment of military assets with the required logistical, organisational and enforcement capacity'. ${ }^{128}$ This opens opportunities for the Security Council to take on a coordinating role in a global response to a global issue. The Security Council has itself 'underscor[ed] that combating this pandemic requires greater national, regional and international cooperation and solidarity, and a coordinated, inclusive, comprehensive and global international response with the United Nations playing a key coordinating role'. ${ }^{129}$ Its previous resolutions addressing the HIV/AIDS epidemic ${ }^{130}$ and the Ebola outbreak in West Africa ${ }^{131}$ also recognised the need for a coordinated international response. Although the Council's delayed response to the COVID-19 pandemic has been criticised as a failure of multilateralism, ${ }^{132}$ these resolutions themselves show that the Council is signalling the importance of multilateralism, cooperation and solidarity over nationalistic approaches and emphasising its role as a global coordinator.

By considering the COVID-19 pandemic as falling within its remit under Article 24(1) and in exercising its powers under the Charter, the Security Council could go even further and play a more active global coordination role in the response to the pandemic. First of all, the Council provides a forum for facilitating an exchange of views among UN Member States on 'the security implications of international health threats, epidemics and pan-

127 See Stefan Elbe, 'Should HIV/AIDS Be Securitized? The Ethical Dilemmas of Linking HIV/AIDS and Security', International Studies Quarterly 50 (2006), 119-144; Gian Luca Burci, 'Ebola, the Security Council and the Securitization of Public Health', 23 December 2014, $<$ http://www.qil-qdi.org $>$.

128 Burci (n. 127).

129 UN Doc. S/RES/2532 (2020), Preambular para. 6.

130 Resolution 1983 (2020), Preambular para. 6.

131 UN Doc. S/RES/2177 (2014), Preambular para. 13.

132 Patrick Wintour, 'What is the Future of the UN in the Age of Impunity?', The Guardian, 23 July 2020. 
demics and the corresponding role of the Security Council in maintaining international peace and security'133 as well as experiences and lessons learned. By putting a situation on its agenda, holding open debates, adopting resolutions, and remaining seized of a matter, the Council may also raise awareness and garner international momentum and political support for addressing certain issues, as was the case with the Ebola outbreak in 2014. ${ }^{134}$ The Security Council also clearly has a role to play in 'promoting and facilitating the appropriate consideration of the impact of COVID-19 in engendering effective approaches to peacebuilding and sustaining peace'. ${ }^{135}$ Beyond peacebuilding, the Security Council could also facilitate international cooperation in logistical matters, for example, by providing a framework (such as a 'global goods coordination mechanism') ${ }^{136}$ to ensure global access to vaccines and other medical technology that may be developed to fight the pandemic. This could overcome concerns of a vaccine 'arms race' in which States treat the development and use of a vaccine as a national security issue or use such technological advances as political leverage. ${ }^{137}$

\section{Challenges of Coordination between Specialised UN Agencies}

This then raises the question of how to delineate fields of competence between the Security Council and specialised UN agencies such as the WHO and how to ensure policy coherence between them. The High Level Panel on Threats, Challenges, and Change already noted in 2004 the need for coordination and cooperation between the WHO and the Security Council and the establishment of procedures for this in response to 'the intentional release of an infectious biological agent or an overwhelming natural outbreak of an infectious disease', including information sharing by the WHO to the Security Council, support by the Security Council of the WHO's investigations and deployment of experts, mandating compliance with the International Health Regulations (IHRs) (as it did in Resolution 2177 with respect to the Temporary Recommendations issued under the IHRs) and setting up of

133 Germany's concept note for the high-level open debate of the Security Council on the theme 'Pandemics and security', (n. 18), para. 10.

134 Pavone (n. 27), 326.

135 Letter Dated 30 July 2020 from the Permanent Representative of Indonesia to the United Nations Addressed to the Secretary-General, UN Doc. S/2020/765, para. 5.

136 Rob Berschinsky, 'UN Security Council Can and Should Create a Global Goods Coordination Mechanism for Coronavirus', 24 March 2020, <https://www.justsecurity.org>.

137 See James Paton, 'A Cold War Has Started over Coronavirus Vaccine with Allegations of Russian Cyberattacks', ThePrint, 17 July 2020. 
cordons sanitaires. ${ }^{138}$ However, in marked contrast to its recognition of the 'central role' of the WHO with respect to Ebola in Resolution 2177, Resolution 2532 does not mention the WHO at all. ${ }^{139}$ The question of the alignment of roles and responsibilities of UN organs has already been raised with respect to Ebola and Resolution 2177, as well as during the 2007 debates on the impact of climate change on international peace and security. ${ }^{140}$ In particular, Maurizio Arcari and Paolo Palchetti astutely asked: 'are the competences of the interested institutional stakeholder, such as the WHO in the case at hand, enhanced or threatened by the ever growing tendency of the SC to cope with questions going well beyond the traditional boundaries of international peace and security?'141

\section{Implications for Collective Security Framework}

The scope of the Security Council's mandate under Article 24(1) may also affect the interpretation and application of other provisions of the Charter, including by broadening the overall Purpose of the United Nations and altering the collective security framework including the prohibition of the use of force. With respect to the latter, Federica Paddeu has argued that since Article 2(4) proclaims that uses of force inconsistent with the Purposes of the United Nations are unlawful and one of those Purposes is the maintenance of international peace and security, an expansion of the concept of international peace and security also broadens the scope of the prohibition of the use of force. ${ }^{142} \mathrm{~A}$ more obvious implication for collective security is a possible expansion of the interpretation of 'threat to the peace' if the term 'peace' is interpreted in a consistently broad manner. Sections II and III already discussed the relationship between these two concepts, which, though distinct and giving rise to distinct legal consequences, have not been consistently differentiated in the Council's practice. However, due to the differing legal

138 A More Secure World: Our Shared Responsibility. Report of the High-Level Panel on Threats, Challenges and Change, 2 December 2004, UN Doc. A/59/565, para. 144.

139 The preamble states that it has 'considered' GA Resolution 74/270, which itself recognises in its preamble 'the central role of the United Nations system in catalysing and coordinating the global response to control and contain the spread of COVID-19, and acknowledging in this regard the crucial role played by the World Health Organization'.

140 Maurizio Arcari and Paolo Palchetti, 'The Security Council as a Global "HealthKeeper"? Resolution 2177 (2014) and Ebola as a Threat to the Peace', Questions of International Law (no. 10 2014).

141 Arcari and Palchetti (n. 140).

142 Federica I. Paddeu, 'Military Assistance on Request and General Reasons Against Force: Consent as a Justification for the Use of Force', Journal on the Use of Force and International Law 7 (2020), 227-269. 
consequences, there may be less political resistance to characterising nontraditional security threats such as pandemics and the climate crisis as an 'endangerment to the maintenance of international peace and security' rather than a 'threat to the peace' and thus a lower (political) threshold for expanding its scope compared to Article 39. ${ }^{143}$

In terms of Chapter VII measures, the collective security architecture that the Security Council exists within was not designed to address these nonmilitary types of threats and those that do not necessarily emanate from an identifiable responsible actor, as the sanctions regime envisaged by Chapter VII makes clear. A feature of these newer, non-traditional security threats may indeed be that they are not directly attributable to a specific actor but have more complex causes which are not suitably addressed through coercive measures. Furthermore, action in response to emerging threats to international peace and security through the Security Council may suffer from a legitimacy deficit since it does not reflect a sovereign equality of States and its response is clearly shaped by geopolitical agendas especially of its permanent members. But at the same time, these very features can also have an advantage since this also empowers the Security Council to take rapid action and 'fill gaps' in international responses. ${ }^{144}$

\section{Conclusion}

Although there is an urgent need for global action to address the COVID19 pandemic, it is still appropriate and necessary to question the longer-term institutional impacts of these actions, including with respect to the Security Council's role. In particular, it is apt to ask whether the Security Council has the required resources and competences to address non-traditional threats to international peace and security, and how multilateral mechanisms can be established or strengthened in order to facilitate the necessary forms of cooperation needed to mitigate global crises such as pandemics. ${ }^{145}$

143 For example, with respect to the Spanish Question (concerning the relationship between the UN and Francoist Spain and in particular whether the situation in Spain endangered international peace and security) the Council's reluctance to make a finding of a 'threat to the peace' was probably based on wariness of imposing coercive measures such as economic sanctions or military measures under Chapter VII, a factor that White argues continues to remain " $\mathrm{t}$ ] he motivating factor behind the Council's finding or not finding a "threat to the peace"' (n. 12), 38.

144 Nilüfer Oral, Panel Discussion, UN to 75 online conference, 9 October 2020.

145 Concept note for the Security Council summit-level debate to be held on 24 September 2020 on the theme 'Maintenance of International Peace and Security: Global Governance after COVID-19', UN Doc. S/2020/883, 3 September 2020, para. 12. 


\section{Conclusion: Reconceptualising Collective Security and the Role of the Security Council}

The COVID-19 pandemic clearly has grave and far-reaching implications globally, nationally, and at the individual level, many of which are immediate and concrete. However, to look beyond the current crisis and consider longterm consequences for the international legal system and the role of a key player within it, the UN Security Council, is not to ignore or downplay this complex reality. Rather, this paper has taken the Security Council's response to the pandemic, in the form of Resolution 2532, as a starting point to argue that the concept of international peace and security - a foundational concept in the modern international legal and institutional order - is broadening. As this paper has argued, this correspondingly expands the mandate of the Council itself, set out in Article 24(1), to maintain international peace and security. Given that the Security Council is empowered to take broad and even binding measures in response to situations falling within the scope of its mandate, including outside Chapter VII, it is relevant to consider which types of threats fall within this scope.

So far, much of the focus on the Security Council's competence and powers has focused on 'threat to the peace' and Chapter VII. But in light of its increasing practice in addressing non-traditional 'threats to/endangerments of international peace and security', including Resolution 2532, we need to better understand the role that the Security Council can play outside traditional peace and security issues. ${ }^{146}$ Existential global threats extend beyond war and require a global response. The current crisis is an opportunity to rethink the conception of international peace and security and the role of the UN Security Council. This corresponds with the overall Purposes of the United Nations, that beyond pacific settlement of disputes and enforcement measures, the Organisation 'also has the purpose and is empowered to take positive and affirmative action in bringing about the conditions essential for peace throughout the world and for its enjoyment'. ${ }^{147}$

146 Oral (n. 144).

147 Goodrich and Simmons (n. 11), 13, citing US Department of State, Charter of the United Nations, Report to the President on the Results of the San Francisco Conference, Publication 2349 (26 June 1945), 68. 